\title{
Dynamics of estuarine phytoplankton assemblages in Mex Bay, Alexandria (Egypt): Influence of salinity gradients
}

\author{
Samia K. Mikhail \\ National Institute of Oceanography and Fisheries, Alexandria, Egypt. \\ e.mail. Mikhail_samia@yahoo.com
}

\begin{abstract}
$\mathrm{M}$ ex Bay, west of Alexandria (Egypt) is a large, shallow and turbid coastal plain estuary of socio-economic importance. Along its salinity gradient (3.30 to 39.64), seven sampling stations were chosen to cover the different habitats. Regionally, four water masses could be defined; the Mediterranean water mass of salinity $>38.5$, mixed Mediterranean of 30 to 38.5, diluted of 10 to 30 and drain water mass of salinity $<10$. Phytoplankton species were grouped into three major types: freshwater, coastal low salinity and euryhaline species. A massive spring bloom characterized the annual production cycle and attributed to Skeletonema costatum. Salinity shares in shaping the structure of diatomdominated communities, and its levels between 30 and 35 seem suitable ecological condition for their growth. A boundary of salinity 3.3-5.1 identified as a critical region for certain freshwater species, mostly cyanophytes. Dinoflagellates existed with salinity above 14.8. Chlorophyll $a$ (average 14.39 $\mu \mathrm{g}^{-1}$ ) reached its maximum in mid summer. Chlorophyll $a$ for cells $<20 \mu \mathrm{m}$ contributed over $65 \%$ of the biomass. During the phytoplankton blooms, the $>$ $20 \mu \mathrm{m}$ cells dominated $(62.73 \%$ of total Chl. a) in May, both fraction size ( $50.1 \%$ and $49.9 \%$, respectively) in July, and the $<20 \mu \mathrm{m}$ cells in September $(67.52 \%)$. No significant correlation was found between any chlorophyll $a$ size fraction and abundances of diatoms, euglenophytes, chlorophytes, and cyanophytes, except for the $>20 \mu \mathrm{m}$ size with dinoflagellate abundances. The distribution patterns of biomass showed relatively high Chl. $a$ (average $15.68 \mu \mathrm{g}$ $\left.1^{-1}, 83.73 \%<20 \mu \mathrm{m}\right)$ at salinity $<10 ; 26.24 \mu \mathrm{g}^{-1}, 58.76 \%<20 \mu \mathrm{m}$ at salinity $10-$ 30 ; and decreased values $\left(6.16 \mu \mathrm{g} 1^{-1}, 58.5 \%<20 \mu \mathrm{m}\right)$ and $0.99 \mu \mathrm{g} 1^{-1}, 66.06 \%$ $<20 \mu \mathrm{m}$ at salinity between $30-38.5$, and $>38.5$, respectively.

Values of the diversity index fluctuated between 0.34 nats (May) and 2.24 nats (September), linked with species diversity and blooming.
\end{abstract}

Keywords: Mex Estuary, phytoplankton, salinity gradients, fractionated chlorophyll $a$.

\section{INTRODUCTION}

Kennish (1986) quoted Pritchard (1967) in defining an estuary as "a semi-enclosed coastal body of water which has a free connection with the open 
sea and within which seawater is measurably diluted with freshwater derived from land drainage".

Much of the high temporal and spatial variability in physical, chemical and biological conditions in estuaries occur through seasonal and interannual variability in freshwater flow (Kimmerer, 2002). Estuaries receiving high organic and inorganic inputs act as nutrient traps, eventually developing into eutrophication processes (Jonge et al., 2002). Globally, these systems have been the focus of research programs aimed at understanding anthropogenic influences (Bricker et al., 1999).

Estuarine systems are characterized by high phytoplankton production (Cloern et al., 1983; Sin et al., 1999; Robson and Hamilton 2003) and pronounced gradients in environmental habitat properties that influence the phytoplankton dynamics and community composition (Troccoli et al., 2004). Beside nutrient availability, the magnitude and position of the turbidity maximum, the water stratification and grazing are important regulating factors (Harrison et al., 1991; Huisman et al., 2001).

Salinity termed by Kinne (1966) an "ecological master factor" in estuaries is highly variable in coastal and estuarine ecosystems (Gasiũnaite, 2000), causing a preferential variability in the primary production (Agawin et al., 2000; Dagg et al., 2004), and phytoplankton composition (Pilkaityte et al., 2004).

Classification of phytoplankton by size, based on fractionated chlorophyll has received much attention because of the potential influence of cell size on the response of phytoplankton populations to their environment (Piontkovski et al., 1995). Observational evidence (Tamigneaux et al., 1999) and conceptual models (Legendre \& Michaud 1998) have pointed to phytoplankton size as the principal mechanism controlling the trophic organization of planktonic communities (Fogg, 1995). However, little is known about sizefractionated biomass in the Mediterranean coastal waters (Polat, 2006).

Over the last decade, many investigations of the phytoplankton standing crop in relation to ambient physical and chemical condition have been carried out in Mex Estuary (e.g., Labib 1997 \& 2000; Mikhail, 1997; 2003a, 2005). The information available strongly suggests the relative importance of nutrient concentrations in the enhancement of its primary production; the bay is a site of intensive phytoplankton blooms, causing recurrent water discoloration from late spring to early autumn, and occasional events of limited invertebrate and fish mortality. However, due to the complexity and non-linearity of the relationships between nutrients, phytoplankton productivity and species composition (Philippart and Cadée, 2000), inorganic nutrients in the bay are not the sole factor that limit the phytoplankton growth, probably unable enough to explain the temporal and spatial distribution patterns in the phytoplankton abundance and composition (Mikhail, 1997). 
In developing a classification system for phytoplankton in Mex estuary, it is important to define regimes of environmental variables that affect its structure in the different parts. The present study, with the main objective to characterize seasonal changes in phytoplankton abundance and taxonomic composition is an attempt to determine how differences in salinity gradients are reflected in the phytoplankton distribution patterns of the different water masses. The dynamic of biomass in terms of two different size classes of chlorophyll $a$ was examined. No previous study in the Mex Estuary has approached the sizefractionated biomass production in conjunction with community composition influenced by salinity gradients. Obtained results are necessary to manage the impact of water quality in estuarine systems.

This study is a part of the project "Effects of industrial, tourist activities and marine transport on physical, chemical and biological characteristics of water and fish populations, west of Alexandria", NIOF, Alexandria.

\section{Study site}

\section{MATERIALS AND METHODS}

The topography of Mex Bay is previously described elsewhere (e.g., Mikhail, 1997). In the last two decades the total monthly amount of discharged water into the bay from Mraiout Lake through Umom Drain (U D) varied from 185.2 to $194.13 \times 10^{6} \mathrm{~m}^{3}$ in spring, $177.9-206.7 \times 10^{6} \mathrm{~m}^{3}$ in summer, 207.52$228.8 \times 10^{6} \mathrm{~m}^{3}$ in autumn, and $204.87-230.17 \times 10^{6} \mathrm{~m}^{3}$ in winter (data obtained from Ministry of Irrigation, Directorate of Mex Pumping Station, Alexandria). In addition, the estuary receives directly industrial wastewater inputs at its western part.

The study was carried out bi-monthly from March 2005 to January 2006. Seven sampling stations were chosen to cover different habitats in the bay; four of them (Sts. 1-4) were defined along a longitudinal transect for about $4 \mathrm{~km}$ away from the coast, and station (7) represents the outer zone towards the west (Fig. 1). Stations $(1 \& 2)$ were located over water depth of $<3 \mathrm{~m}$, and the outer stations over $16 \mathrm{~m}$.

\section{Sampling strategy}

At each station, surface and above bottom temperature and salinity were measured using a thermometer $\left( \pm 0.1^{\circ} \mathrm{C}\right)$, and an induction salinometer (Beckman RS-7B). The water column transparency $\left(D_{S}\right)$ was measured by using a white Secchi disc $\left(35 \mathrm{~cm}\right.$ diameter), and the light extinction coefficient $\left(k_{\mathrm{e}}\right)$ was calculated at Sts. 1 and 2, where $k_{e}=1.4 / D_{\mathrm{S}}$, as recommended by Holmes (1970), and at other stations applying $k_{e}=1.7 / D_{\mathrm{S}}$ (Sherwood and Gilbert 1974). 


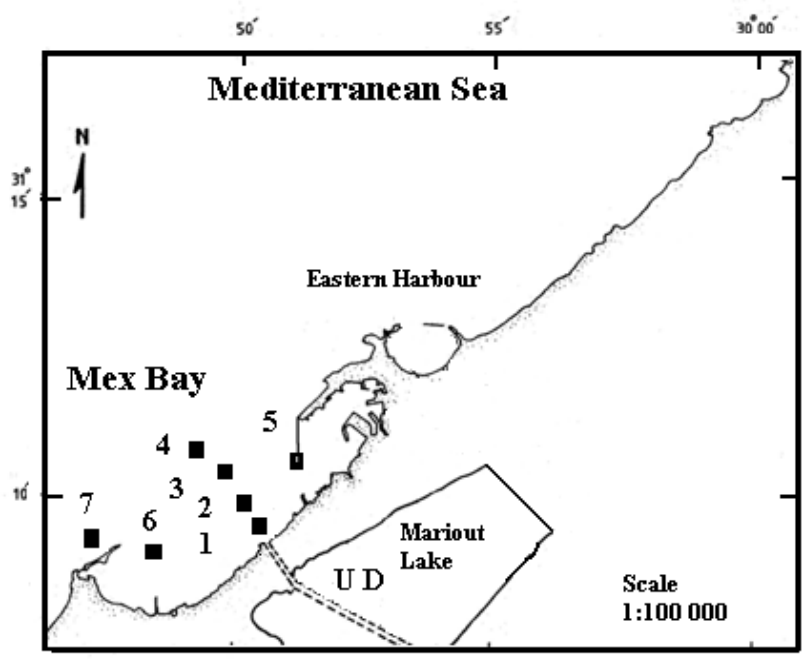

Figure 1. Mex Bay and location of the sampling stations.

The seawater were collected using water sampler from the surface water layer (approx. $0.5 \mathrm{~m}$ depth) and above the bottom, and preserved with $5 \mathrm{ml}$ of sodium tetraborate buffered formalin and with a few drops of Lugol's solution. Phytoplankton species were observed using inverted microscope, identified (Tomas, 1997; Tanaka, 2002), and the standing crop by number (units $\mathrm{l}^{-1}$ ) was determined according to the procedure described by Utermöhl (1958), the units comprise cells, colonies and filaments.

For pigment analyses, two liters of seawater were collected in polyethylene bottles wrapped in black plastic bags and kept cool until filtering. One liter was passed through a net with $20-\mu \mathrm{m}$ mesh size, and the retained was washed with filtered seawater then filtered using GF/F filters ( $47 \mathrm{~mm}$ diameter) to calculate chlorophyll $a$ of phytoplankton cells $>20 \mu \mathrm{m}$, and one liter was filtered directly using GF/F filters (total Chl. a). Chlorophyll $a$ concentrations were measured spectrophotometrically according to method given by Parsons et al. (1984). Chlorophyll $a$ of $<20 \mu \mathrm{m}$ size fraction was calculated by subtracting the $>20 \mu \mathrm{m}$ size fraction from total chlorophyll $a$.

The phytoplankton diversity index was estimated according to Shannon and Weaver (1968), and the linear and multiple regression analysis were calculated. 


\section{Physical environment}

\section{RESULTS}

Generally, the shallow waters of Mex estuary allow great temporal and spatial changes in temperature. The macro-variations are strictly related to the seasonal conditions, while the micro-variations are affected by the daily discharged water input. Surface water temperature oscillated normally between $14.54^{\circ} \mathrm{C}$ in winter (January) and up to $31^{\circ} \mathrm{C}$ in summer (July). The surface water of station (1) was warmer than the entire bay from March to November, and the reverse happened in January.

Surface salinity fluctuated regionally from 3.30 to 39.64. Salinity changes were governed by the mixing of inflowing of higher salinity Mediterranean waters with the discharged waters from Umum Drain. In response, surface salinity in the central part of the bay dropped to the values 29.94 in July and 14.48 to 21.7 in November. The near bottom salinity exhibited a narrower fluctuation range (37 to 39.49). The thermo-haline stratification developed by May, and lasted until November.

Using salinity values as an indicator, four water masses can be defined; the Mediterranean water mass of salinity $>38.5$, mixed Mediterranean of salinity 30 to 38.5 , diluted water mass of salinity 10 to 30 and drain water mass of salinity $<10$. The latter was always restricted to the nearest area of Umoum Drain. The spatial distribution of salinity (Fig. 2) showed the mixed Mediterranean water mass to spread over most of the bay in March and May. Meanwhile, the Mediterranean water mass occupied the east and west offshore. The distribution patterns changed in July and September as the diluted water mass dominated the entire bay, with some interference of higher salinity at the east offshore in the first month. This pattern explains strong jet effect of the discharged water forcing the salinity intrusion seawards. The mixed Mediterranean water mass prevailed in November. However, the entering of the Mediterranean water mass from west offshore in January limits its expansion towards the middle part of the bay.

The Secchi disc readings fluctuated between 0.1 and $0.5 \mathrm{~m}$ at St. 1 , the most influenced site by discharged waters. Subsequently, light extinction coefficient $\left(k_{\mathrm{e}}\right)$ varied between 2.8 (March \& November) and 14 (July \& September). The measurements at the middle part of the bay varied between 0.3 and $6 \mathrm{~m}$; the highest at station 6 in January. The calculated light coefficient for these stations was maximum in September (1.17-4.67). Values between 1 to 11 $\mathrm{m}$ were measured at St. 7, which seems to be less affected by the fresh water inflow; light extinction coefficient varied between 0.13 in January, and 1.4 in September. 

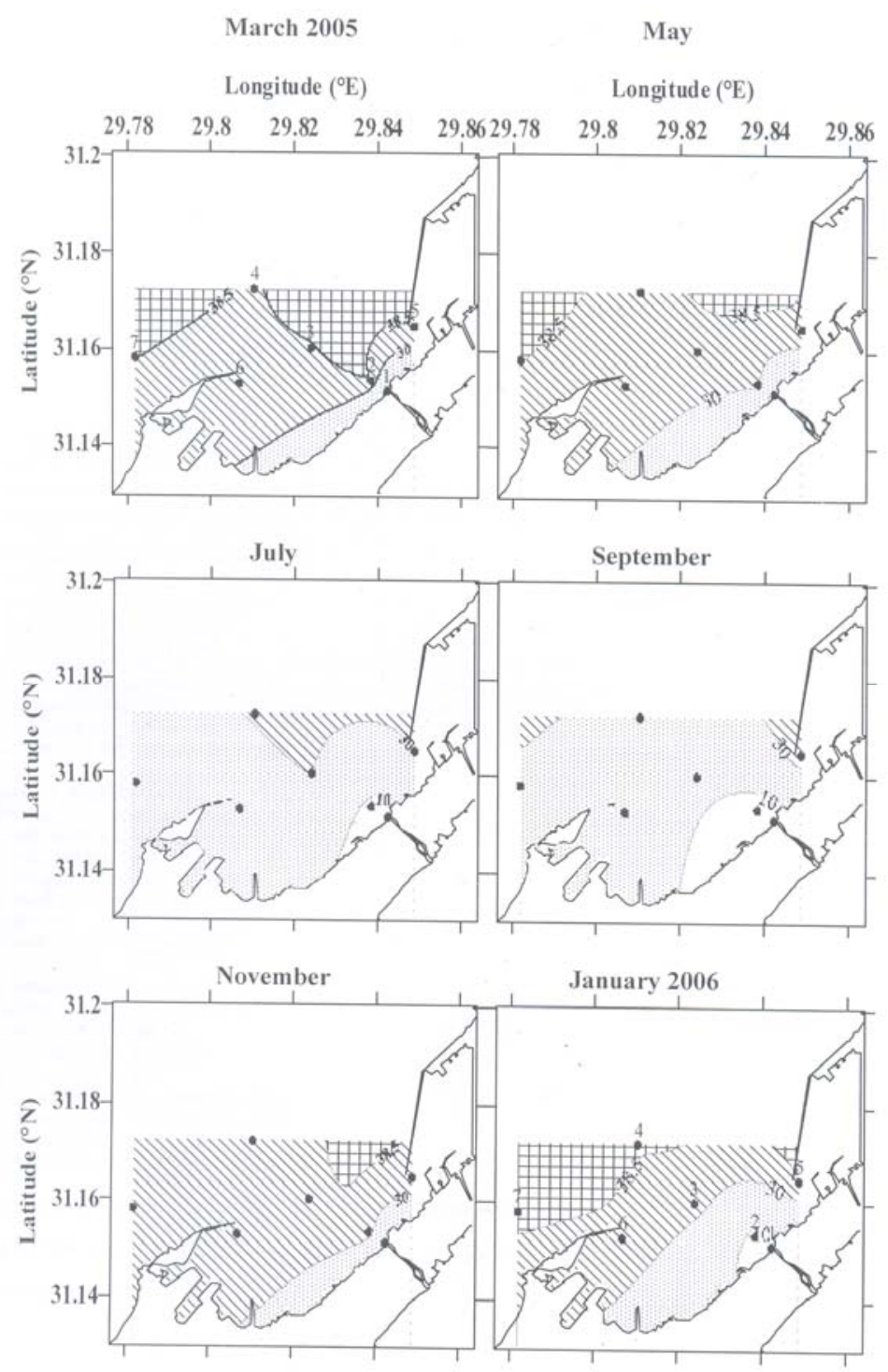

Fig. 2. Spatial distribution of salinity with different water masses Salinity $<10$ 10-30 30-38.8 $>38.5$ 田

\section{Phytoplankton variability and community structure}

Phytoplankton abundances exhibited remarkable spatial and temporal variability (Table 1). The annual surface average of phytoplankton density was $17.54 \times 10^{6}$ units $1^{-1}$. The surface layer generally showed a higher density than the subsurface $\left(0.72 \times 10^{6}\right.$ units $\left.1^{-1}\right)$. Station 5 gained the highest phytoplankton abundance during March, July, September 2005, and January 2006. It is mainly 
due to the increased number of diatoms (33.7-96.8\% of the total phytoplankton). The lower density was recorded at station 7 (except in July and September).

Low surface production was observed during March 2005 and January 2006, associated with expected lower temperature. In March Skeletonema costatum (maximum $1.56 \times 10^{6}$ cells $1^{-1}, 41.6 \%$ of the total, St.5) and Cyclotella spp., $\left(1.28 \times 10^{6}\right.$ cells $1^{-1}, 34.3 \%$, St.5) were the dominant species. During January Nitzschia spp., $\left(2.21 \times 10^{6}\right.$ cells $1^{-1}, 71.4 \%$, St.5) dominated. A major peak was recorded in May, it was a red tide period with brown water discoloration covering most of the stations; the standing crop showed its highest value all over the year, minimum at St. 7 and maximum at St. 6. The bloom was mainly attributed to $S$. costatum, which attained the highest density of $225.5 \times 10^{6}$ cells $^{-1}$ (93.2\% to the total phytoplankton) at St. 6. The Chlorophycean Tetraspora spp. (maximum of $116.2 \times 10^{6}$ cells $1^{-1}$, St.2) and Coenolamellus sp. $\left(1.74 \times 10^{6}\right.$ cells $1^{-1}$, St.2) shared in active role the visible bloom. The second peak was recorded during July. Cyclotella spp., mainly C. glomerata $\left(11.62 \times 10^{6}\right.$ cells $1^{-1}, 19.39 \%$, St.5) and microflagellates spp., $\left(32.2 \times 10^{6}\right.$ cells $1^{-1}, 53.73 \%$, St.5) were the causative organisms. A gradual decrease in numbers was observed during September and November. Rhizosolenia spp., (10.98x $10^{6}$ cells $1^{-1}, 53.2 \%$, St.5), Nitzschia spp. and Ankstrodesmus spp., dominanted in September. Again, S. costatum was the major constituent in November.

Table 1. Spatial and temporal variations of the phytoplankton standing crop (unitsx $10^{6} 1^{-1}$ ) S: Surface, B: Bottom -: No data

\begin{tabular}{|c|c|c|c|c|c|c|c|c|c|c|c|c|}
\hline \multirow[b]{2}{*}{ Month } & \multirow{2}{*}{$\begin{array}{c}\text { St. } 1 \\
\text { S }\end{array}$} & \multirow{2}{*}{$\begin{array}{c}\text { St. } 2 \\
\text { S }\end{array}$} & \multicolumn{2}{|c|}{ St. 3} & \multicolumn{2}{|c|}{ St. 4} & \multicolumn{2}{|c|}{ St. 5} & \multicolumn{2}{|c|}{ St. 6} & \multicolumn{2}{|c|}{ St. 7} \\
\hline & & & $\mathbf{S}$ & B & $\mathrm{S}$ & B & $\mathbf{S}$ & B & $\mathrm{S}$ & B & $\mathbf{S}$ & B \\
\hline March & 1.26 & 0.52 & 1.87 & 0.13 & 2.35 & 0.57 & 3.75 & 0.53 & 0.57 & 0.12 & 0.07 & 0.09 \\
\hline May & 5.49 & 122.89 & 78.19 & 0.63 & 17.66 & 0.46 & 17.50 & 0.50 & 241.97 & 0.16 & 0.49 & 1.08 \\
\hline July & 0.95 & 2.06 & 11.91 & - & 10.88 & 6.90 & 59.06 & 3.74 & 13.72 & 0.28 & 17.21 & 0.12 \\
\hline September & 2.58 & 2.52 & 9.82 & 0.33 & 8.40 & 0.25 & 20.69 & 0.76 & 12.68 & 0.38 & 17.02 & 0.18 \\
\hline November & 5.69 & 2.73 & 16.44 & 0.23 & 4.62 & 0.04 & 4.97 & 2.36 & 7.59 & 0.05 & 1.90 & 0.01 \\
\hline January & 1.59 & 1.62 & 0.64 & 0.06 & 0.61 & 0.07 & 3.09 & 0.83 & 0.85 & 0.10 & 0.11 & 0.03 \\
\hline Average & 2.93 & 22.06 & 19.81 & 0.23 & 7.42 & 1.38 & 18.18 & 1.45 & 46.23 & 0.18 & 6.13 & 0.25 \\
\hline
\end{tabular}

The number of phytoplankton species identified reaches more than 200 species (97 genera) belonging to eight groups. Diatoms (39 genera, 91 species, and average $10.48 \times 10^{6}$ cells $1^{-1}$ ) contributed the main bulk of the community (62.4\% of the total at the surface and $69.1 \%$ at the bottom). Chlorophytes (29 genera, 43 species, average $5.04 \times 10^{6}$ units $1^{-1}, 14.5 \%$ and $6.3 \%$ ) Tetraspors sp. was the dominant species. The area just in front of the outlet gained high densities in September due to the increased numbers of Ankstrodesmus sp. Dinoflagellates (11 genera, 23 species, average $0.27 \times 10^{6}$ cells $1^{-1}, 2.5 \% \& 6.2 \%$ ) 
had its highest contribution during July mainly of Gymnodinium catenatum and Prorocentrum triestinum. Euglenophytes (4 genera, 22 species) contributed an average of $0.07 \times 10^{6}$ cells $1^{-1}(1.4 \% \& 2.7 \%)$, its highest density occurred in July. Euglena spp. showed tolerance to a wide range of salinity and attained its maximum density during May and July at salinity 30-37. Cyanophytes (10 genera and 17 species, average $0.04 \times 10^{6}$ units $1^{-1}, 0.7 \% \& 0.1 \%$ ) were mainly observed at the near shore stations (1\&2). Silicoflagellates (2 genera and 2 spp.) showed scattered occurrence during May, July, September and November 2005. Crysophyceae was represented by one species (Ochromonas sp.) recorded during May, September 2005 and January 2006. Cryptophyceae (1 species, Cryptomonas sp.) appeared once in January 2006.The Microflagellates (unidentified, average $1.64 \times 10^{6}$ cells $1^{-1}, 17.9 \% \& 15.4 \%$ ) were perennial forms, even in winter, with its main existence during July (Sts. 5\&6) and their minimum density appeared at the lowest salinity region (St. 1).

Salinity ranges of the dominant diatoms were broad (Table 2). Yet, salinity level between 30 and 35 creates suitable ecological condition for the growth. The major diatom species forming the main components of communities are considered coastal water forms in Alexandria waters of low salinity.

Table 2. Salinity with the dominant diatoms (M. D maximum density cellsx $10^{6} 1^{-1}$ )

\begin{tabular}{|l|c|c|c|c|c|c|}
\hline \multicolumn{1}{|c|}{ Species } & Salinity range & Main Salinity & M.D & Salinity range & St. No. & Month \\
\hline S. costatum & $21.71-39.06$ & $34.79-36.81$ & 225.5 & 34.79 & 6 & May \\
\hline Cyclotella spp. & $3.7-38.1$ & $22.57-30.4$ & 11.62 & 29.94 & 5 & July \\
\hline Thalassiosira spp. & $3.7-36.14$ & $29.94-30.3$ & 3.11 & 29.94 & 5 & July \\
\hline Rhizosolenia spp. & $4.34-35.44$ & $14.48-30.5$ & 13.39 & 30.5 & 7 & July \\
\hline Nizschia spp. & $4.06-39.64$ & $14.48-38.57$ & 6.57 & 35.44 & 5 & Sep. \\
\hline
\end{tabular}

The euryhaline diatoms, responsible for the observed bloom periods and dinoflagellates with the different water masses, are given in Table (3).

Table 3. Maximum density (cellsx $10^{6} 1^{-1}$ ) of euryhaline diatom and dinoflagellate species with the major water masses

\begin{tabular}{|l|c|c|c|c|c|c|c|c|c|}
\hline \multicolumn{1}{|c|}{ Species } & $\begin{array}{c}\text { Water mass } \\
10-30\end{array}$ & St. & $\mathrm{M}$ & $\begin{array}{c}\text { Water mass } \\
30-38.5\end{array}$ & St. & $\mathrm{M}$ & $\begin{array}{c}\text { Water mass } \\
>38.5\end{array}$ & St. & $\mathrm{M}$ \\
\hline Asterionella glacialis & 0.01 & 2 & Mar. & 0.15 & 4 & Mar. & 0.02 & 7 & Jan. \\
\hline Chaetoceros spp. & 0.02 & 1 & Nov. & 0.28 & 5 & Jan. & 0.01 & 7 & Mar. \\
\hline Cyclotella spp. & 11.62 & 5 & July & 1.28 & 5 & Mar. & 0.004 & 7 & Mar. \\
\hline Hemiaulus hauckii & 0.01 & 2 & Mar. & 0.05 & 3 & Mar. & 0.04 & 7 & Mar. \\
\hline Lauderia borealis & 0.03 & 2 & Nov. & 0.8 & 3 & Nov. & 0.03 & 7 & Mar. \\
\hline Leptocylindrus minimus & 1.11 & 5 & Sep. & 0.2 & 5 & Mar. & 0.02 & 5 & Jan. \\
\hline Pseudo-nitzschia seriata & 13.0 & 5 & July & 0.8 & 3 & Nov. & 0.27 & 7 & Jan. \\
\hline Rhizosolenia spp. & 10.99 & 5 & Sep. & 6.6 & 6 & Sep. & 0.71 & 7 & Sep. \\
\hline Skeletonema costatum & 5.1 & 1 & Nov. & 225.5 & 6 & May & 0.01 & 7 & May \\
\hline Thalassiosira spp. & 3.1 & 5 & July & 0.027 & 6 & Jan. & 0.12 & 5 & Jan. \\
\hline Gymnodinium excavatum & 2.69 & 5 & July & 0.59 & 6 & Sep. & - & - & - \\
\hline Prorocentrum triestinum & 1.4 & 5 & July & 0.33 & 6 & May & - & - & - \\
\hline Scrippsiella trochoidea & 0.1 & 5 & Sep. & 0.59 & 6 & Sep. & - & - & - \\
\hline
\end{tabular}


The common freshwater forms were Lepocinclis ovum, Phacus trypanon, Spondylomorum quaternarium, Actinastrum sp., Ankistrodesmus falcatus var. acicularis, Botryococcus braunii, Chlorosarcina minor, Coelastrum sphaericum, Gloeocapsa minima, Chlorella, Oöcystis, Staurastrum, Tetraspora, Westella, Anabena, Oscillatoria, and Phormidium species.

\section{Phytoplankton biomass (Chlorophyll a)}

Phytoplankton production and community composition were determined by total chlorophyll $a$ and size-fractionated chlorophyll analysis. Generally, chlorophyll $a$ content runs in parallel with the numerical standing crop. Apparent discrepancy however, between peaks of Chl. $a$ and phytoplankton density occurred frequently at stations $1 \& 2$. Deviations are due to the dominance of large-sized freshwater, colonies and filaments, species transferred from Lake Mariout Several major periods of chlorophyll $a$ accumulation occurred, accompanying the phytoplankton blooms. Surface Chl. $a$ ranged from 0.48 to $41.84 \mu \mathrm{g} \mathrm{l}^{-1}$ (average, $14.39 \mu \mathrm{g} \mathrm{l}^{-1}$ ). The maximum surface values between $30-$ $41.9 \mu \mathrm{g} . \mathrm{l}^{-1}$ were detected during May (St. 6), July (St.3, 4 \& 5) and September (St. 5, $6 \& 7$ ), while the minimum appeared in winter (January, $2.63 \mu \mathrm{g}^{-1}$ ). The highest bottom value $\left(25.39 \mu \mathrm{g} . \mathrm{l}^{-1}\right)$ recorded at station 4 during July (Table 4), coincident with the maximum production. Regionally, chlorophyll $a$ distribution showed the minimum concentrations at about $0.5 \mathrm{~km}$ away from the stream site (St. 2, average $\left.9.42 \mu \mathrm{g}^{-1}\right)$, and at $4.5 \mathrm{~km}$ (St. 7) outside the estuary $\left(9.3 \mu \mathrm{g} \mathrm{l} \mathrm{l}^{-1}\right.$ ).

Table (4). Monthly phytoplankton biomass (Chl. $a \mu \mathrm{g}^{-1}$ ) at different stations at the bottom from March 2005 to January 2006

\begin{tabular}{|c|c|c|c|c|c|c|c|}
\hline \multirow{2}{*}{ Stations } & \multicolumn{6}{|c|}{ Month } & \multirow{2}{*}{$\begin{array}{l}\text { Annual } \\
\text { Average }\end{array}$} \\
\hline & March & May & July & September & November & January 2006 & \\
\hline 3 & 2.45 & 1.34 & - & 0.73 & 1.62 & 2.88 & 1.8 \\
\hline 4 & 2.50 & 3.11 & 25.39 & 0.61 & 1.31 & 0.57 & 5.6 \\
\hline 5 & 3.79 & 1.63 & 10.69 & 1.06 & 1.73 & 2.00 & 3.5 \\
\hline 6 & 1.32 & 0.54 & 1.78 & 0.39 & 1.34 & 1.34 & 1.1 \\
\hline 7 & 1.27 & 1.19 & 1.84 & 0.33 & 1.10 & 1.92 & 1.3 \\
\hline
\end{tabular}

The fractionated chlorophyll $a$ (Fig. 3) generally, showed the values $<20 \mu \mathrm{m}$ (picoplankton-nanoplankton) to be higher than $>20 \mu \mathrm{m}$, however, Chl. $a$ percentage in each size fraction declared high variability with salinity gradients. The contribution of large cells ( $>20 \mu \mathrm{m})$ to total concentrations of chlorophyll $a$ increased downstream during summer, whereas that of small cells $(<20 \mu \mathrm{m})$ increased towards the open sea most of the year. The size-fractionation data, on average base, suggested that over $65 \%$ of the chlorophyll $a$ was associated with cells of $<20 \mu \mathrm{m}$. Chlorophyll $a$ content $>20 \mu \mathrm{m}$ showed, generally higher values at station 1 and 2 due to the dominance of large size chlorophycean and 
filamentous cyanophycean species. It was also of higher values during September at Sts. 5, $6 \& 7$.
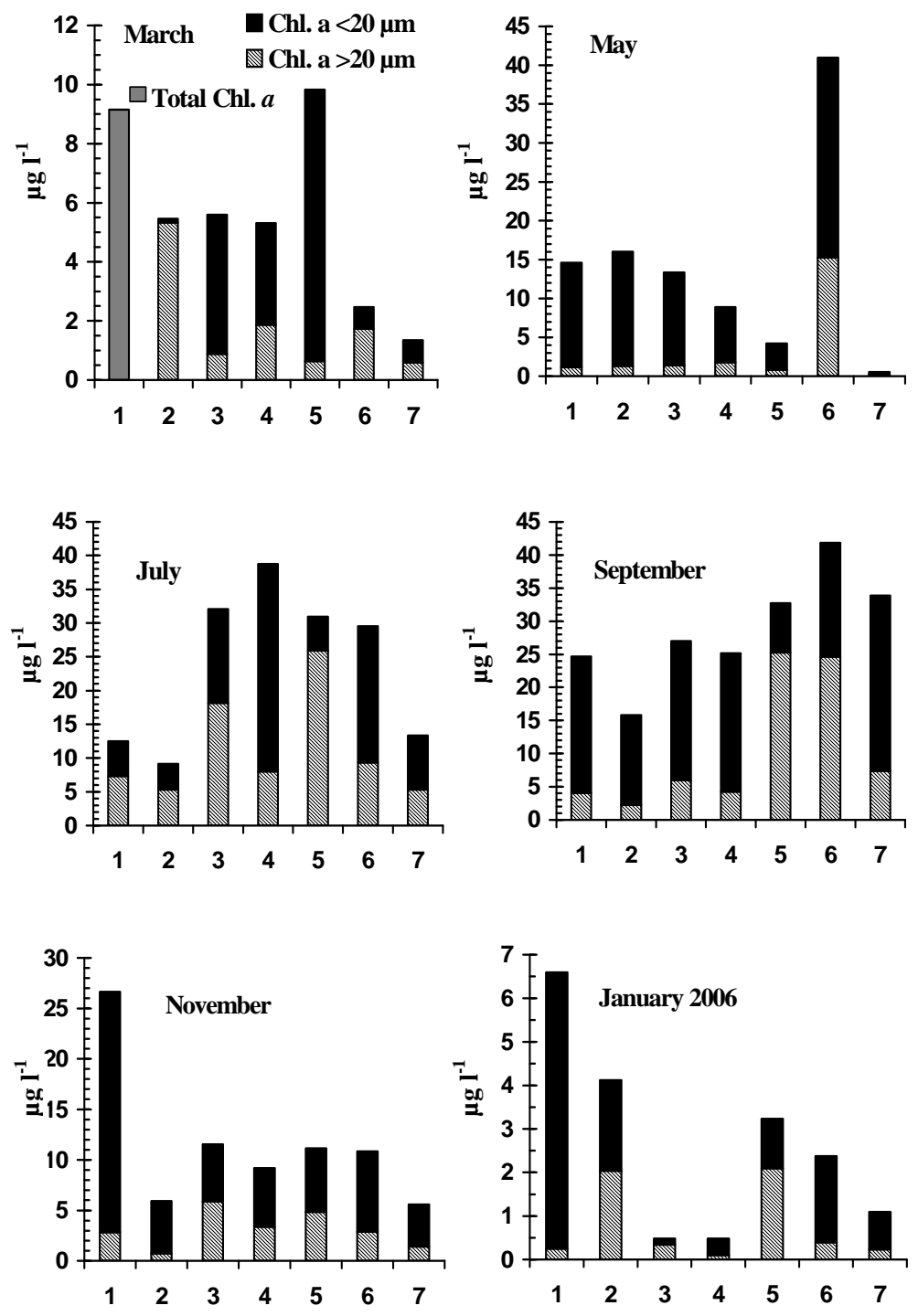

Fig. (3). Surface fractionated Chl. a content at the different stations from March 2005 to January 2006.

During the phytoplankton blooms, the contribution of both size-fraction $(>20 \mu \mathrm{m}$ and $<20 \mu \mathrm{m})$ to the total exhibited remarkable changes. Thus, the $>20$ 
$\mu \mathrm{m}$ cells dominate the biomass $(62.73 \%$ of total chl $a)$ in May, both fraction size (50.1\% and $49.9 \%$, respectively) in July, while in September, the small-sized cells contributed $67.52 \%$ (average $18.18 \mu \mathrm{g} \mathrm{l}^{-1}$ ).

Based on mean values (Table 5), chlorophyll $a$ at salinity $<10$ was relatively high $\left(15.68 \mu \mathrm{g}^{-1}\right)$ mostly of the size fraction $<20 \mu \mathrm{m}(83.73 \%$ of the total). A maximum concentrations $\left(26.25 \mu \mathrm{g} \mathrm{l}^{-1}\right)$ was measured at salinity between 10 and $30(<20 \mu \mathrm{m}, 58.76 \%)$ and rapidly decreased to $6.16 \mu \mathrm{g} \mathrm{l}^{-1}(<20 \mu \mathrm{m}, 58.5 \%)$ at salinity between $30-38.5$ and $1.0 \mu \mathrm{g}^{-1}(<20 \mu \mathrm{m}, 66.06 \%)$ at salinity $>38.5$.

Table 5. Size-fractionated chlorophyll $a$ at the different salinity ranges.

\begin{tabular}{|l|c|c|c|c|c|c|c|c|}
\hline & \multicolumn{2}{|c|}{ Salinity $<\mathbf{1 0}$} & \multicolumn{2}{c|}{ Salinity 10-30 } & \multicolumn{2}{c|}{ Salinity $\mathbf{3 0 - 3 8 . 5}$} & \multicolumn{2}{c|}{ Salinity $>\mathbf{3 8 . 5}$} \\
\cline { 2 - 9 } & $\mathbf{2 0} \mathbf{~} \mathbf{g}$ & $<\mathbf{2 0} \mathbf{~} \mathbf{g}$ & $\mathbf{> 2 0} \mathbf{~ g}$ & $<\mathbf{2 0} \mathbf{~ g}$ & $\mathbf{2 0} \mathbf{~ g g}$ & $<\mathbf{2 0} \mathbf{~ g}$ & $\mathbf{2 0} \mathbf{\mu g}$ & $<\mathbf{2 0} \mathbf{~ g}$ \\
\hline Mean & 2.61 & 13.07 & 10.95 & 15.3 & 2.49 & 3.67 & 0.34 & 0.65 \\
\hline Minimum & 0.24 & 5.12 & 2.24 & 3.82 & 0.11 & 0.14 & 0.20 & 0.34 \\
\hline Maximum & 7.35 & 23.81 & 25.92 & 30.74 & 5.89 & 7.97 & 0.59 & 0.87 \\
\hline$\%$ & 16.27 & 83.73 & 41.24 & 58.76 & 41.50 & 58.5 & 33.94 & 66.06 \\
\hline
\end{tabular}

\section{Diversity Index}

The highest phytoplankton diversity values ( $>2$ nats) at the surface were observed during September at Sts. 2, 3\& 4 and station 1 during March and May (Fig. 4), accompanied by high number of species and the dominance was shared by several species. The lowest values ( $<0.4$ nats) during May (Sts. 2 and 6) attributed to the predominance of the sole species; Tetraspora sp. (94.5\%) and $S$. costatum (93.2\%) at the two stations, respectively. Station 1 (average 1.71 nats) was the most diversified one due to the high number of species (average of 45 spp.) and low density (average $3.25 \times 10^{6}$ units $1^{-1}$ ), while station 7 showed the lowest diversity value (1.14 nats) coincided with the lowest average of phytoplankton production $\left(6.13 \times 10^{6}\right.$ units $\left.1^{-1}\right)$ and lowest number of species (average 24 species).

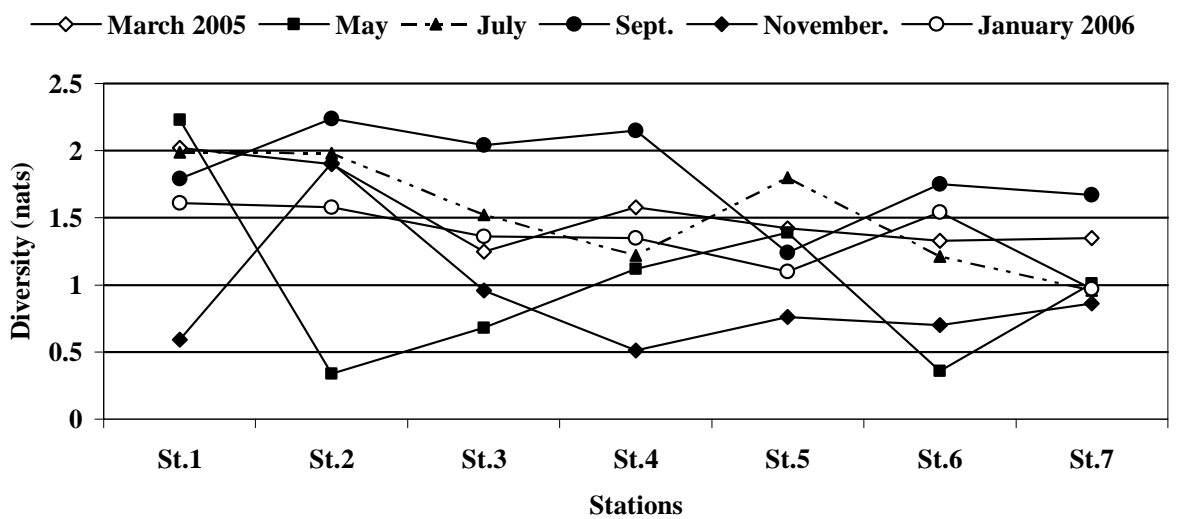

Fig. 4. Surface values of diversity index at different stations 


\section{DISCUSSION}

The study shows that Mex estuary, like many other estuaries worldwide (e.g., Chaparro et al., 2008) has been under environmental stress by eutrophication processes, where the physical and phytoplankton dynamics are strongly influenced by the runoff of freshwater from land and the exchange of water with the adjacent open sea. The salinity limit at 38.5 was far chosen by ElMaghraby and Halim (1965) to be the inner boundary of the neritic Mediterranean waters off Alexandria.

The distinct salinity gradients had an immense impact on the phytoplankton productivity, distribution, and composition, in accordance with several studies (e.g., Gowen et al., 1995). The species composition in the Mex estuary was grouped mainly into three types: (1) freshwater; (2) coastal low salinity; and (3) euryhaline species. The freshwater forms are coming mostly from Lake Mariout (Mikhail, 1997). Species exclusive to brackish waters were not well identified, but salinity gradients from freshwater to seawater promoted a transition from freshwater to euryhaline-marine phytoplankton communities as the degree of marine influence, or salinity increases. All diatoms living in transitional zones between marine and freshwater might be considered as marine or freshwater taxa with different degrees of euryhalinity (Carpelan, 1978).

Salinity appeared to be an important factor shaping the structure of diatom-dominated communities, and each water mass was associated with a different abundance, in accordance with Gowen et al. (1995). The data stresses the salinity variations, rather than absolute salinity tolerance, as the major environmental factor influencing the distribution of organisms in Mex estuary as reported in the Baltic Sea (Attrill, 2002).

Phytoplankton, submitted to temporal and regional scales displayed complex and extremely variable seasonal patterns of abundance and distribution. Such variability might be considered as a natural bioindicator (Livingston, 2001). The dominance of a few species in Mex estuary reflected signs of heavy eutrophication (Telesh, 2006). The variability in space indicated the area in front of the drain mouth is relatively less productive than the entire bay. Expected high turbidity and light availability might be important factors that controlled the phytoplankton growth (May et al., 2003). The same result was detected at the outer station of the bay towards the west as influenced by high salinities (Wasmund, 1997).

The annual cycle of the phytoplankton production was characterized by a massive bloom of diatoms-chlorophytes in late spring, minor peaks of diatomsphytoflagellates-chlorophytes during summer-early autumn, and relatively lower phytoplankton density in winter, with diatoms reappearing as the dominating taxonomic group. Almost similar results were reported (Bianchi et al., 2002). The dominance and persistent occurrence of diatoms in all sites throughout the different seasons agree with the results of other studies in the Mediterranean estuaries (Ahel et al. 1996), as well as world wide (Gameiro et al., 2007). As in 
many estuaries (e.g., Gayoso, 1998) the spring bloom was the most characteristic event in the annual phytoplankton cycle. Several authors (e.g., Lopes et al., 2007) reported the blooming of chlorophytes in estuarine waters during late spring and summer. Generally, diatoms dominate the spring bloom in temperate coastal waters (e.g., Bianchi et al., 2002). However, deviations from this pattern have been reported (e.g., Tamelander and Heiskanen, 2004).

The strongest response for the development of thermo-haline stratification was observed within the smaller-sized diatoms and chlorophycean species in late spring in accordance with Winder (2007), as well as for the growth of microflagellates and dinoflagellates during summer. Several authors (e.g., Wirtz and Wiltshire, 2005) stressed the critical role of the cessation of mixing in summer for the predominance of flagellates in marine ecosystems.

\section{Phytoplankton structure and biomass with salinity gradients}

Both freshwater and marine species responded strongly to salinity gradients. The salinity boundary at 3.3-5.1 was defined a critical limit for certain freshwater species in the present study, which seems relatively lower (salinity at 4-7) that reported by Kinne (1971) for physiological stress of freshwater species.

There was a tendency for a relative decrease in species ratio of diatoms to total phytoplankton from $94.3 \%$ (Mikhail, 1997) to $89.6 \%$ (Labib, 1997) to reach $63.79 \%$ in the present work. A similar change has been recorded in other estuaries (e.g., Gao and Song, 2005). The euryhaline, S. costatum, common taxa in estuaries (Badylak et al., 2007) represented the major component. Its massive abundance in different salinity regions and water quality conditions was recorded (Harold et al., 2006).

Dinoflagellates appeared with salinity between 14.76 and 38.57 , mainly represented by $P$. triestinum (main occurrence in July). This species at salinity range 22.5-36.5 caused recurrent blooms in the Mex bay and at its eastern vicinity during the last decade (Mikhail 97; Labib 97; 2000).

Salinity during its seasonal cycle was strongly related to the phytoplankton density $(\mathrm{r}=-0.62$, significant at $\mathrm{p}<0.05, \mathrm{n}=42)$. The most pronounced salinity effect was observed for cyanophytes $(r=-0.68$, significant at $\mathrm{p}<0.05, \mathrm{n}=42)$, more distinctly between May and September $(\mathrm{r}=-0.75$, significant at $\mathrm{p}<0.05, \mathrm{n}=21)$. Salinity during these warm seasons seems to have some effect on the variability of diatoms and euglenophytes $(r=0.29$ and 0.30 , insignificant at $\mathrm{p}<0.05, \mathrm{n}=21$ ).

\section{Biomass}

The development of different water masses resulted in changes in the distribution of phytoplankton biomass, in agreement with the results of several authors (e.g., Gowen et al., 1995). The study showed that the small-sized phytoplankton species are the major primary producer for the whole year cycle in the Mex ecosystem and contributed greatly to Chl. $a$ concentration, similar to that reported in an estuarine environment (Shiomoto, 1997), but, in contrary with others (Y1lmaz et al., 1997). 
During the stratification periods, phytoplankton biomass dominated by the $<20 \mu \mathrm{m}$ cells. However, with the development of vertical mixing in January the contribution of the $>20 \mu \mathrm{m}$ size increased, similar to the results of Davis (1982). Several authors (e.g., Kormas et al., 2002) previously discussed reasons for the great contribution of large diatoms during the winter under mixed condition. The high concentration of Chl. $a>20 \mu \mathrm{m}$ at some stations during September was mainly due to the dominant of three Rhizosolenia species of small size, but these species form long chains and hard to be separated. The same result was found during January 2006, when the dominant species was the chain forming species Pseudo-nitzschia seriata.

The temporal variations in phytoplankton biomass were not related to corresponded phytoplankton abundance $(\mathrm{r}=0.42, \mathrm{n}=42$, insignificant at $\mathrm{P}<0.05$ ), reflects variability in community composition. No statistically significant correlations were found between any Chl. $a$ size fraction and diatom, euglenophyte, chlorophyte, and cyanophyte abundances. However, diatoms show slightly higher correlation with the $>20 \mu \mathrm{m}$ and $<20 \mu \mathrm{m}$ fractions $(\mathrm{r}=0.33$ and 0.35 , insignificant at $\mathrm{p}<0.05, \mathrm{n}=42$, respectively). The $>20 \mu \mathrm{m}$ size fraction was significantly correlated with dinoflagellate abundances $(\mathrm{r}=0.61$, $\mathrm{p}<0.5, \mathrm{n}=42$ ).

\section{Multiple Regression Analysis}

The stepwise statistical model was computed to understand the relation between the numerical standing crop, Chl. $a<20 \mu \mathrm{m}$ and Chl. $a>20 \mu \mathrm{m}$ (as dependent variables) and the measured physico-chemical conditions (independent variables). The analyses were done based on the surface sampling from March 2005 to January 2006.

The model equation for the standing crop by number: Standing crop $\left(\right.$ unit $\left.\mathrm{l}^{-1}\right)=2181647-1.67442 *$ Temperature $-1.29587^{*}$ nitrate $\left(\mathrm{R}^{2}=86 \%\right.$, significant at 0.05 level, $t$ test) indicates temperature as an important factor might affect the changed phytoplankton abundance.

The model equation for Chl. $a<20 \mu \mathrm{m}$ : Chl. $a<20 \mu \mathrm{m}\left(\mu \mathrm{g} \mathrm{l^{-1 }}\right)=$ $34.08873-2.53437 *$ Sal. $+1.977 *$ dissolved oxygen $\left(\mathrm{R}^{2}=76 \%\right.$, significant at 0.05 level, $t$ test) illustrates the importance of salinity.

The model equation for Chl $a>20 \mu \mathrm{m}$ : Chl. $a>20 \mu \mathrm{m}\left(\mu \mathrm{g} \mathrm{l}^{-1}\right)$ $=-120.859+0.451531 *$ Temperature $+0.82923 *$ Salinity $+1.376936^{*}$ nitrate $\left(\mathrm{R}^{2}=90 \%\right.$, significant at 0.05 level, $t$ test) shows temperature and salinity as main factors regulating Chl. $a<20 \mu \mathrm{m}$ variability.

\section{CONCLUSION}

It is necessary to consider different salinity regimes for classification of ecological status by means of phytoplankton taxonomic composition, particularly in an ecosystem where plenty of nutrients are not limiting factors for phytoplankton growth. Analyses of phytoplankton size structure are necessary to understand controls on phytoplankton dynamics and to manage water quality in 
discharged waters-dominated estuarine systems. Better understanding of the structure of phytoplankton communities in estuarine environments requires studies that are more specific on size classes. The growing socio-economic development of Mex estuary requires the implementation of more investigations in order to improve the knowledge of diversity and ecology of the biotic communities that inhabit the estuary; this type of information will contribute toward the sustainable management of this ecosystem.

\section{ACKNOWLEDGMENT}

The author deeply appreciates the encouragement and the great help received from the PI of the project, Prof. Zeinab M. El-Sherif (NIOF) offering facilities needed to complete this work, and in preparation of the text, which enhanced its quality.

\section{REFERENCES}

Agawin, N.S.R.; Duarte, C.M. and Agust1', S. (2000). Nutrient and temperature control of the contribution of picoplankton to phytoplankton biomass and production. Limnology and Oceanography, 45: 591-600.

Ahel, M.; Barlow, R. G. and Mantoura, RF.(1996). Effect of salinity gradients on the distribution of phytoplankton pigments in a stratified estuary. Marine Ecology Progress Series, 143:289-295.

Attrill, M. J. (2002). A testable linear model for diversity trends in estuaries. J. of Animal Ecology, 71: 262-269.

Badylak, S.; Phlips, E. J.; Baker, P.; Fajans, J. and Boler, R. (2007). Distributions of phytoplankton in Tampa Bay Estuary, U.S.A. 2002-2003. Bulletin of Marine Science, 80(2): 295-317.

Bianchi, T. S.; Rolff, C.; Widbom, B. and Elmgren, R. (2002). Phytoplankton Pigments in Baltic Sea Seston and Sediments: Seasonal Variability, Fluxes, and Transformations. Estuarine, Coastal and Shelf Science, 55: 369-383.

Bricker, S.B.; Clement, C. G.; Pirhalla, D. E.; Orlando, S. P. and Farrow, D.R.G. (1999). National Estuarine Eutrophication Assessment: Effects of Nutrient Enrichment in the Nation's Estuaries. NOAA National Ocean Service, Silver Spring, MD.

Carpelan, L. H., (1978). Evolutionary euryhalinity of diatoms in changing environments, Nova Hedwig. 29: 489-526. 
Chaparro, O. R.; Segura, C. J.; Montiel, Y. A. ; Thompson, R. J. and Navarro, J. M. (2008). Variations in the quantity and composition of seston from an estuary in southern Chile on different temporal scales. Estuarine, Coastal and Shelf Science, 76(4): 815-830.

Cloern, J.E.; Alpine, A.; Cole, B.; Wong, R.; Arthur, J. and Ball, M. (1983). River discharge controls phytoplankton dynamics in the northern San Francisco Bay Estuary. Estuarine, Coastal and Shelf Science, 16:415-429.

Dagg, M.J.; Benner, R.; Lohrenz, S. and Lawrence, D. (2004). Transport and transformation of dissolved and particulate materials on continental shelves induced by large rivers: plume processes. Contenental Shelf Research, 24:833-858.

Davis, C.O.(1982). The importance of understanding phytoplankton life strategies in the design of enclosure experiments. In Marine Mesocosms, Eds., Grice, G.D. and M.R. Reeve. Springer-Verlag, New York, pp. 323332.

El-Maghraby, A.M. and Halim, Y. (1965). A quantitative and qualitative study of the Plankton of Alexandria waters. Hydrobiologia, 25(1-2): 221-238.

Fogg, G.E., (1995). Some comments on picoplankton and its importance in the pelagic ecosystem. Aquatic Microbiology and Ecology, 9:33-39.

Gameiro, C.; Cartaxana, P. and Brotas, V. (2007). Environmental drivers of phytoplankton distribution and composition in Tagus Estuary, Portugal. Estuarine, Coastal and Shelf Science, 75(1-2): 21-34.

Gao, X. and Song, J. (2005). Phytoplankton distributions and their relationship with the environment in the Changjiang Estuary, China. Marine Pollution Bulletin, 50: 327-335.

Gasiũnaite, Z. R.(2000). Coupling of the limnetic and brackishwater plankton crustaceans in the Curonian lagoon (Baltic Sea). International Review of Hydrobiology, 85: 649-657.

Gayoso, A. M.(1998). Long-term phytoplankton studies in the Bahia Blanca Estuary, Argentina, ICES. Journal of Marine Science, 55: 655-660.

Gowen, R. J.; Stewart, B. M.; Mills, D. K. and Elliott, P. (1995). Regional differences in stratification and its effect on phytoplankton production and 
biomass in the northeastern Irish Sea. Journal of Plankton Research, 17: 753-769.

Harold, G.; Marshall, H. G.; Lacouture, R. V. ; Buchanan, C. and Johnson, J. M. (2006). Phytoplankton assemblages associated with water quality and salinity regions in Chesapeake Bay, USA. Estuarine, Coastal and Shelf Science, 69(1\&2): 10-18.

Harrison, P. J.; Clifford, P. J. and Cochlan, W.P. (1991). Nutrient and phytoplankton dynamics in the Fraser River plume, Strait of Georgia, British Columbia, Marine Ecology Progress Series, 70: 291-304.

Holmes, R.W. (1970). The Secchi disc in turbid coastal waters, Limnology and Oceanography, 15: 688-694.

Huisman, J. P.; van Oostveen and Weissing, F. J. (2001). Critical depth and critical turbulence: two different mechanisms for development of phytoplankton blooms, Limnology and Oceanography, 44: 1781-1787.

Jonge, V. N.; Elliot, M. and Orive, E. (2002). Causes, historical development, effects and future challenges of a common environmental problem eutrophication. Hydrobiologia, 475/476:1-19.

Kennish, M. J. (1986). Ecology of Estuaries, Volume I: Physical and Chemical Aspects. CRC Press, Boca Raton, Florida.

Kimmerer, W. J. (2002). Effects of freshwater flow on abundance of estuarine organisms: physical effects or trophic linkages? Marine Ecology Progress Series, 243: 39-55.

Kinne, O. (1966). Physiological aspects of animal life in estuaries with special reference to salinity, Netherlands Journal of Sea Research, 3: 222-244.

Kinne, O. (1971). Salinity: animals-invertebrates. In Marine Ecology, Vol. 1. Environmental Factors, Ed. Kinne, O., John Wiley \& Sons, New York, pp. 821-996.

Kormas, K. A.; Garametsi, V. and Nicolaidou, A. (2002). Size fractionated phytoplankton chlorophyll in an Eastern Mediterranean coastal system (Maliakos Gulf, Greece). Helgoland Marine Research, 56:125-133.

Labib, W. (1997). Eutrophication in Mex Bay, Alexandria (Egypt). Environmental Studies and Statistical Approach. Bulletin of National Institute of Oceanography and Fisheries, A.R.E., 23: 49-68. 
Labib, W. (2000). Impact of land-based sources on marine environment: Phytoplankton blooms within an annual cycle. Chemistry and Ecology, 17: 75-89.

Legendre, L. and Michaud, J.(1998). Flux of biogenic carbon in oceans: sizedependent regulation by pelagic food webs. Marine Ecology Progress Series, 164:1-11.

Livingston, R. J.(2001). Eutrophication processes in coastal systems: origin and succession of plankton blooms and effects on secondary production in Gulf Coast estuaries. Center for Aquatic Research and Resource Management. Florida State University, CRC Press. 327 pp.

Lopes, C. B.; Lillebø, A. I.; Dias, J. M.; Pereira, E.; Vale, C. and Duarte, A.C. (2007). Nutrient dynamics and seasonal succession of phytoplankton assemblages in a Southern European Estuary: Ria de Aveiro, Portugal. Estuarine, Coastal and Shelf Science, 71(3-4): 480-290.

May, C. L.; Koseff, J. R.; Lucas, L. V. ; Cloern, J. E. and Schoellhamer, D. H. (2003). Effects of spatial and temporal variability of turbidity on phytoplankton blooms. Marine Ecology Progress Series, 254: 111-128.

Mikhail, S. K. (1997). Ecological Studies of the Phytoplankton in Mex Bay. Ph. D. thesis, Faculty of Science, Alexandria University, 266 pp.

Mikhail, S. K. (2003a). Increasing occurrence of Red Tide outbreaks off Alexandria (Egypt) causing occasional fish and invertebrate mortality. J. of Aquatic Biology and Fisheries 7: 65-90.

Mikhail, S. K. (2005). Application of coupled 3D hydrodynamic and ecosystem model (Finest). Estimation of Limiting Growth Factors and Primary Production in a Highly Dynamic Eutrophicated Marine Basin, Alexandria (Egypt). Proceeding of the International Workshop on "The Protection of Coastal \& Marine Environment", 9-11 November 2005, Izmir -Turkey, pp. $189-195$.

Parsons, T.R.; Maita, Y. and Lalli, C.M. (1984). A Manual of Chemical and Biological Methods for Seawater Analysis, Pergamon Press, Oxford, 173 pp.

Philippart, C. J. M. and Cadée, G. C. (2000). Was total primary production in the western Wadden Sea stimulated by nitrogen loading? Helgolander Marine Research, 54: 55-62. 
Pilkaityte, R.; Schoor, A. and Schubert, H. (2004). Response of phytoplankton communities to salinity changes: a mesocosm approach, Hydrobiologia, 513:27-38.

Piontkovski, S. A.; Williams, R. and Melnik, T. A. (1995). Spatial heterogeneity, biomass and size structure of plankton of the Indian Ocean: some general trends. Marine Ecology Progress Series, 117: 219-227.

Polat, S. (2006). Size fractionated distribution of the phytoplankton biomass in the İskenderun Bay, Northeastern Mediterranean Sea, Fresh Environmental Bulletin, 15: 417-423.

Pritchard, D. W. (1967). What is an estuary: Physical viewpoint. In Estuaries, Ed., Lauff, G.H. American Association for the Advancement of Science, Publication 83. Washington, D.C.

Robson, B. J. and Hamilton, D. P. (2003). Summer flow event induces a cyanobacterial bloom in a seasonal western Australian estuary. Marine and Freshwater Research, 54:139-151.

Shannon, C. E. and Weaver, W. (1968). The mathematical theory of communication. Iünios Press (Vrbana).117 pp.

Sherwood, B. I. and Gilbert, R. G. (1974). On the universality of the Poole and Atkins Secchi disc extinction equation. Journal of Applied Ecology, 11: 399-401.

Shiomoto, A. (1997). Size-Fractionated Chlorophyll a Concentration and Primary Production in the Okhotsk Sea in October and November 1993, with Special Reference to the Influence of Dichothermal Water. Journal of Oceanography, 53: $601-610$.

Tamelander, T. and Heiskanen, A. S. (2004). Effects of spring bloom phytoplankton dynamics and hydrography on the composition of settling material in the coastal northern Baltic Sea. Journal of Marine Systems, 52(14): $217-234$.

Tamigneaux, E.; Legendre, L.; Klein, B. and Mingelbier, M. (1999). Seasonal dynamics and potential fate of size-fractionated phytoplankton in a temperate nearshore environment (western Gulf of St. Lawrence, Canada). Estuarine, Coastal and Shelf Science, 48: 253-269. 
Tanaka, M. (2002). Illustrations of the Japanese Freshwater Plankton. The University of Nagoya Press, 579 pp.

Telesh I. V. (2006). Plankton of the Baltic estuarine ecosystems with emphasis on Neva Estuary: a review of present knowledge and research perspectives. Marine Pollution Bulletin, 49(3): 206-219.

Tomas,C.R. (1997). Identifying Marine Phytoplankton. Academic Press, 835 pp.

Troccoli, G. L.; Herrera-Silveira, J. A. and Comín, F. A.(2004). Structural variations of phytoplankton in the coastal seas of Yucatan, Mexico, Hydrobiologia, 519: 85-102.

Utermöhl, H. (1958). Zur vervollkommnung der quantitativen phytoplankton Methodik. Mitteilungen-Internationale Vereiningung für Limnologie,9:1-38.

Wasmund, N. (1997). Occurrence of cyanobacterial blooms in the Baltic Sea in relation to environmental conditions. Internationale Revue der gesamten, Hydrobiologie, 82: 169-184.

Winder, M. (2007). Reorganization of phytoplankton communities linked to physical forcing. ESA/SER Joint Meeting, 5-10 August, 2007, San Jose McEnery Convention Center-San Jose, California. eco.confex.com/ eco/ 2007/ techprogram/P4185.HTM

Wirtz, K.W. and Wiltshire, K. (2005). Long-term shifts in marine ecosystem functioning detected by inverse modeling of the Helgoland Roads timeseries, Journal of Marine Systems, 56: 262-282.

Yılmaz, A.; Salihoğlu, I.; Tuğrul, S. and Baştürk, Ö. (1997). Pollution loads from land-based sources of Turkish NE Mediterranean coasts and their impacts on the marine environment, $3^{\text {rd }}$ Int. Conf. on the Environmental Management of Enclosed Coastal Seas (EMECS): August 10-15 1997, Stocholm, pp. 165-167. 